\title{
Multicultural Indonesia in Geographical and Cultural Perspectives
}

\author{
Dr Tod Jones \\ School of Built Environment, \\ Curtin University \\ Perth, Australia \\ T.Jones@curtin.edu.au
}

\begin{abstract}
This paper argues that there are unresolved tensions between the forces driving cultural diversity in Indonesia, namely Indonesia's demographic transition and urbanization, and the state's approach to multiculturalism. It argues that multiculturalism under the New Order can be defined as hierarchical multiculturalism, where ethnic groups are aligned with the administrative units of the state at different levels and locations. This form of multiculturalism is a key reason for the proliferation of administrative units (pemekaran) since decentralization, and is in tension with the powerful forces for socio-demographic change mentioned earlier. I suggest a placebased multiculturalism would be more appropriate for Indonesia given the trend towards increasing cultural diversity.
\end{abstract}

Keywords-multiculturalism, demographic transition, urbanization, cultural policy, Indonesia

\section{INTRODUCTION}

Explanations of Indonesian history and politics invariably use historical analysis of vertical and horizontal divisions. Horizontal divisions refer to class divisions between elite, peasant, middle and working classes. Vertical divisions refers to ethnic, religious and geographical (such as Java/outer islands) divisions. These divisions are then complicated by other binaries such as historical divisions between hierarchical agricultural societies and networked trading communities, and between the metropolitan superculture of modernity and the social structures of traditional societies. Clifford Geertz cut through this complexity with his concept of aliran or streams that grouped together parts of these divisions to explain vertical groupings and political affiliations and behaviours [1]. Political analysis that began during the Suharto period (following the work of [2]), while acknowledging these alignments, emphasised patronage networks rather than sociohistorical groupings as politics was understood as disconnected vertically and therefore more usefully explained through the actions of political elite. Analysis in the 1990s sought to identify a growing middle class that it was thought could drive democratic reforms as they sought greater freedom of expression [3]. The forced resignation of Suharto in 1998 was read by some [4] as the victory of this group. However, as democratic reforms slowed then stalled during the reform era, observers returned to analysis of patronage networks to explain political behaviour and history, but following decentralisation and the ethnic and religious violence in a few provinces at this time, with a new emphasis on the lower levels of the vertical groupings [5][6].

The topic of this paper is cultural diversity, which is a set of aspects of vertical divisions that are increasingly thought of as cultural, and addressed through a range of different policies. I define cultural diversity widely here, encompassing both ethnic diversity as well as other axes along which groups define their identity including religion and gender. My focus here is ethnicity. Cultural diversity can be managed through a range of policy positions. Multiculturalism is therefore a policy position that seeks to acknowledge and manage the diversity of identities and communities that are located within a geographical area. It can be conceived at the national level, or lower levels such as the province, city/regency, district or even village. Multiculturalism is opposed to assimilation, where a dominant group insists that new entrants to the area they control adopt their beliefs and practices, particularly in public spaces and forums. ${ }^{1}$

My brief overview of political analysis of Indonesia is important for understanding Indonesia's cultural diversity for two reasons. First, cultural diversity is a structural feature of these accounts, but also was rarely used to explain recent national politics or history before the Reform Era. In fact, since the 1950s it has been the horizontal relationships between political elites in particular that has dominated analysis, and diversity has been managed through patronage. Explanations for the violence in Maluku following the resignation of Suharto, for example, have been explained by some commentators as the failure of patronage networks [7] that manage and contain these vertical divisions, and now decentralisation is being judged to have been successful not because it delivered the economic or efficiency gains expected, but because it has managed cultural diversity [8]. However, it also be noted that the Indonesia state has pursued a policy of multiculturalism since the mid-1950s that is largely ignored in political analysis due to the emphasis on patronage.

${ }^{1}$ The famed 'melting pot' of the USA in the early twentieth century was a form of assimilation as it insisted that immigrants to the USA adopt a similar ethos and set of values. Immigrants went into the imagined melting pot and came out 'cleaned' of ethnic associations [9]. Arguably a version of this was considered for Indonesia, as I explore in the second section below. 
Cultural diversity has therefore been seen as a defining characteristic of Indonesian society, but is generally analysed as the background to political networks rather than a dynamic structural force, and it is viewed as managed through dynamic and flexible patronage networks rather than official policies.

This raises my second point; despite its importance, there are few accounts of the forces that are driving cultural diversity in Indonesia today below the national level. Cultural diversity at the national level allows broad summaries of the percentages of Muslims or Javanese, the number of ethnic groups and indigenous languages, but it gives us little detail about cultural diversity in Indonesia and the issues that Indonesian multiculturalism faces. Such analysis requires attention to lower levels. In particular, analysis of cultural diversity needs to look to contemporary trends. While this is an oversight in analysis, there are reasons why this has not occurred. The first is the legacy of the New Order's policy of not allowing discussion of SARA: suku bangsa, agama, ras, antar-golongan. Statistics on ethnicity only began to be collected in the 2000 census after the end of the New Order era. However, the 2000 census was plagued by problems of poor execution and undercounting, with an estimated 4.5 million Indonesians not counted ([10]; see also [11]). Hence the 2010 census, which was well executed [11], is the first that will provide an accurate picture of Indonesia's ethnic diversity, and can be compared to 2000 with some caveats to provide an indication of longer term trends.

The first section of my paper examines contemporary cultural diversity in Indonesia from a geographical perspective with a focus in particular on the social forces that are driving contemporary changes in cultural diversity, in particular urbanisation but and (as background) Indonesia's demographic transition. I also draw attention to some of the important differences in both cultural diversity and rates of change in different areas. The second section addresses multiculturalism as a policy of the Indonesian state through analysis of cultural policy in Indonesia historically and through the new cultural policy legislation passed earlier this year. In my summary, I draw together the two sections, drawing attention to some of the tensions between what we know from the data and Indonesia's approaches in cultural and other areas of policy.

\section{LITERATURE REVIEW}

The most important driver of change in Indonesia since independence is the demographic transition of its population. Demographic transition refers to a process where a population that has more young people, low life expectances and large families transitions, through what is thought of as four stages, caused by economic and social changes, to a population that has more elderly people, longer life expectancies, and small families. This transition is accompanied by a nutritional transition (away from locally-grown, plant-based diets with the health risks largely of undernutrition to eating more protein with the health risks largely of overnutrition), and a health transition (from communicable diseases like malaria, cholera to noncommunicable diseases like obesity and cancer). The extent of this transition is best demonstrated through the population pyramids in Figure 1 below taken from [11] comparing 1970, 2010 and 2050 (the dotted lines). Between
1970 and 2010, Indonesia's population has shifted from being very young (43\% of Indonesia's population in 1970 was under $15)$ to much more evenly spread across the 0-45 age groups. This is a consequence of Indonesians living longer, becoming better educated, and women gaining more economic freedom and control over reproduction (leading to less children). The demographic transition has occurred across most of Asia, and Indonesia is transitioning slightly more slowly than other countries in the region like Thailand and Vietnam [11]. These changes reflect a greatly changed society and economy. While there are still large numbers of young people, they are a smaller proportion of the population and they are higher educated, and more likely to move for education and employment [12]. The changing economy also moves populations from rural areas to urban areas, and also between provinces and islands. These are the drivers of shifts in cultural diversity.
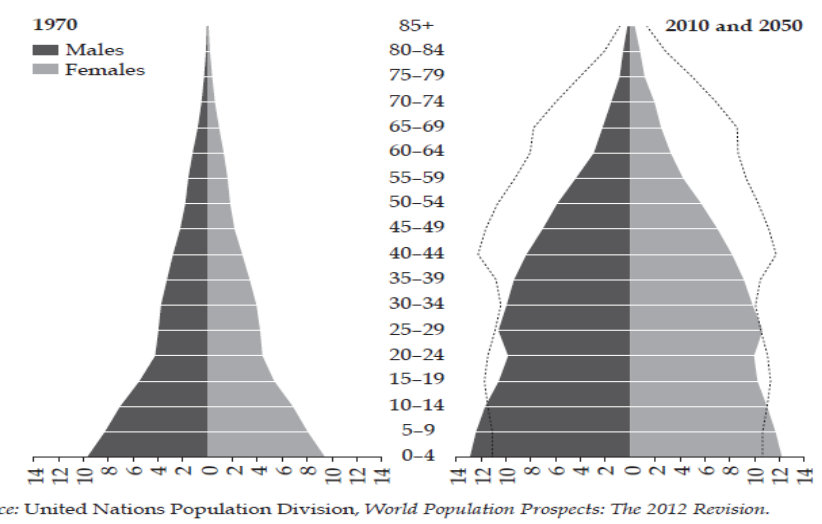

Note: The projected age distribution for 2050 is represented by the dashed lines.

Fig 1: Age distributions of Indonesia 1970, 2010 and 2050 (population in millions) [11].

Multiculturalism seeks to manage the cultural diversity of relations between Indigenous ethnicities, Indigenous ethnicities and large settler populations (in settler societies like Australia, New Zealand and Canada), and increasingly the relationships between the larger settled ethnicities and smaller, more recent migrant communities. Multiculturalism in Australia tends to refer to the policies that seek to manage and assist ethnic populations who arrived in Australia in larger numbers after World War II as the result of shifts in migration policies away from, first, the United Kingdom and Ireland, and second, away from white people. The flavour of multiculturalism in Australia is therefore international. This is different to Indonesia where multiculturalism addresses the ethnic diversity that was present in the country before the twentieth century, and in particular the relationships between Indigenous ethnic groups, although we should not forget the large population of Chinese Indonesians who should also be considered when discussing multiculturalism. ${ }^{2}$ Due to these differences, Multiculturalism has quite different meanings in nation-states where there is consistent migration into the country (international immigration) than it has in countries like Indonesia which have consistent migration out of the country (international migration). There are between 3 and 6

2 The number of foreigners in Indonesia only amounts to 73, 217 [13]. 
million people in the Indonesian diaspora (Muhidin, 2014, p. 317 ), so Indonesians are contributing to cultural diversity in other countries. $^{3}$

The 2010 Indonesian census identified 1331 ethnic categories that [13] classified into 600 ethnic groups. Javanese are by far the largest ethnic group constituting $40.05 \%$ of the population according to the 2010 census, followed by Sundanese (15.51\%), Malay (3.70\%), Batak $(3.58 \%)$, Madurese $(3.03 \%)$ then Betawi $(2.87 \%)$ (see Table 1 below from [13]. Banjarese are the tenth largest with 4.1 million people constituting 1.34 percent of Indonesia's population. The Chinese are the only non-Indigenous group in the top 15 and constitute 1.20 percent. While these nationallevel statistics are important, they tell us little about cultural diversity as they do not explain the patterns of ethnic mixing within geographical regions. At the level of islands, Java is more homogenous than the other islands with the dominant ethnic group on average 87.56 percent of the population at the district level (see table 2 from [14], but there are important differences between western Java and the rest of Java due to the presence of Jakarta (which I explore below). The most homogenous populations were in Central Java $(97.9 \%$ Javanese) and Yogyakarta $(96.5 \%)$ followed by Gorontalo $(89.1 \%)$, West Sumatra (87.3\% Minangkabau), and Bali $(85.5 \%)$. The most diverse provinces were North Maluku (10.8\% Tobelo), Maluku (12.7\% Butonese), West Papua (14.8\% Javanese) and East Nusa Tengara (19.9\% Atoni). An important difference in the culturally diverse provinces is between provinces that have a large number of indigenous ethnic groups (like North Maluku and Maluku) and provinces that have a large number of migrant groups (Javanese, Bugis, Banjarese). The Javanese are particularly important due to their numbers. They constitute the largest ethnic group is 132 districts, 52 of which are outside Java.

TABLE 1: COMPOSITION OF ETHNIC GROUPS IN INDONESIA [13]

\begin{tabular}{|c|c|c|c|c|c|c|c|}
\hline \multirow[b]{2}{*}{ Ethnic group } & \multicolumn{4}{|c|}{ New Classitication' } & \multicolumn{3}{|c|}{ Intial Classefication" } \\
\hline & Rank & Numbar & $\begin{array}{l}\text { Percortage of } \\
\text { total population }\end{array}$ & $\begin{array}{l}\text { Percentage of } \\
\text { al indonesians }\end{array}$ & Rank & Numbor & $\begin{array}{l}\text { Percentage of } \\
\text { at indonesians }\end{array}$ \\
\hline Javanese & 1 & $94,843,073$ & 40.05 & 40.06 & 1 & $05,217,022$ & 40.22 \\
\hline Sundanese & 2 & $36,704,944$ & 15.50 & 15.51 & 2 & $36,701,670$ & 15.50 \\
\hline Malay & 3 & $8,753.791$ & 3.70 & 3.70 & 9 & $5,386,399$ & 2.27 \\
\hline Bataḱ & 4 & $8,466,969$ & 3.58 & 3.58 & 3 & $8,466,969$ & 3.58 \\
\hline Madurese & 5 & $7,179.356$ & 3.03 & 3.00 & 5 & 7, 179,356 & 3.03 \\
\hline Beawi & 6 & $6,807,968$ & 2.87 & 28 & 6 & $6,807,968$ & 2.88 \\
\hline Mnangkabau & 7 & $6,462,713$ & 2.73 & 2.73 & 7 & $6,462,713$ & 2.73 \\
\hline Buginese & 8 & $6,415,103$ & 2.71 & 2.71 & 8 & $6,359,700$ & 2.69 \\
\hline Bantenese & 9 & $4,642,389$ & 1.96 & 1.96 & & na & na \\
\hline Banjarese & 10 & $4,127,124$ & 1.74 & 1.74 & 13 & $4,127,124$ & 1.74 \\
\hline Balinese & 11 & $3,924,908$ & 1.66 & 1.68 & 15 & $3,946,416$ & 1.67 \\
\hline Acennese & 12 & $3,404,109$ & 1.44 & 1.44 & & na & na \\
\hline Dayak & 13 & 3.219 .626 & 1.36 & 1.36 & 17 & $3,009,494$ & 1.27 \\
\hline Sasak & 14 & $3,175,006$ & 1.34 & 1.34 & 16 & $3,173,127$ & 1.34 \\
\hline Chinese & 15 & $2,832.510$ & 1.20 & 1.20 & 18 & $2,832,510$ & 1.20 \\
\hline $\begin{array}{l}\text { Others from Sulawesi island } \\
\text { Ethnic groups from South }\end{array}$ & & - & - & - & 4 & $7,634,262$ & 3.22 \\
\hline $\begin{array}{l}\text { Sunatera Province } \\
\text { Ethnic oroups trom Banten }\end{array}$ & & - & - & - & 10 & $5,119,581$ & 2.16 \\
\hline $\begin{array}{l}\text { Provinos } \\
\text { Pand }\end{array}$ & & - & - & - & 11 & $4,657,784$ & 1.97 \\
\hline
\end{tabular}

3 Skilled Indonesians migrate to developed countries like Australia, USA, the Netherlands and so on. Unskilled Indonesians migrate temporarily and sometimes illegally to countries including Malaysia, Singapore, and the Middle East.

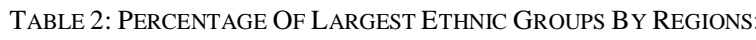
INDONESIA, 2010 [14]

\begin{tabular}{|c|c|c|c|c|c|c|c|}
\hline \multicolumn{2}{|l|}{ Regional Variable } & \multirow{2}{*}{$\begin{array}{c}\text { Minimum } \\
12.95\end{array}$} & \multirow{2}{*}{$\begin{array}{l}\text { Mean } \\
71.90\end{array}$} & \multirow{2}{*}{$\begin{array}{c}\text { Maximum } \\
99.72\end{array}$} & \multirow{2}{*}{$\begin{array}{c}\text { Median } \\
78.96\end{array}$} & \multirow{2}{*}{$\begin{array}{c}\begin{array}{c}\text { Std. } \\
\text { Deviation }\end{array} \\
25.14\end{array}$} & \multirow{2}{*}{$\frac{\mathrm{N}}{399}$} \\
\hline Type of Districts & Regencies & & & & & & \\
\hline & Cities & 13.79 & 62.50 & 97.13 & 64.69 & 25.21 & 98 \\
\hline \multirow[t]{2}{*}{ Region } & Outside Java & 12.95 & 64.60 & 99.57 & 65.99 & 24.65 & 379 \\
\hline & Java & 31.21 & 87.56 & 99.72 & 96.30 & 19.18 & 118 \\
\hline \multirow[t]{7}{*}{ Island } & Sumatera & 27.54 & 66.37 & 99.57 & 66.23 & 22.50 & 151 \\
\hline & Java & 31.21 & 87.56 & 99.72 & 96.30 & 19.18 & 118 \\
\hline & $\begin{array}{c}\text { Bali and Nusa } \\
\text { Tenggara }\end{array}$ & 29.61 & 81.56 & 98.78 & 90.88 & 17.88 & 40 \\
\hline & Kalimantan & 26.18 & 57.08 & 98.12 & 54.55 & 20.96 & 55 \\
\hline & Sulawesi & 17.73 & 68.57 & 98.83 & 75.22 & 24.36 & 73 \\
\hline & Maluku & 17.80 & 43.34 & 90.48 & 35.72 & 22.30 & 20 \\
\hline & Papua* & 12.95 & 54.66 & 98.35 & 48.23 & 30.41 & 40 \\
\hline Total & & 12.95 & 70.05 & 99.72 & 76.47 & 25.40 & 497 \\
\hline
\end{tabular}

Note: This refers to the Land of Papua, the Indonesian part of the Island of New Guinea. Source: Calculated from tabulations provided by BPS-Statistics Indonesia.

This brings us to internal migration. Internal migration can be divided into lifetime migration, or people who have migrated at some point in their life, and recent migration, or people who have migrated in the last 5 years. Internal migration is significant in Indonesia, with 27.8 million people migrating permanently [15]. This is an increase from 8.2 percent in 1990 to $11.7 \%$ of the population in 2010 . Indonesians move for many reasons. While I discuss urbanisation in more detail below, its importance is apparent in Figure 2 when looking at destination provinces. The three largest destinations, Jakarta, West Java and Banten, are driven by the megacity of Jakarta and its neighbours. The employment opportunities and amenities of urban areas are the largest driver of internal migration. We can also see the effects of the transmigration policies of the 1970s and 1980s, in particular in Lampung and South Sumatra, and the attraction of the expanding resource economies of Riau Islands and East Kalimantan. The Javanese are the main lifetime movers with the majority moving to the western parts of Java (see figure 3), but also to southern Sumatra and other provinces to seek economic opportunities. The island geography of Indonesia matters more in 2010 than it did in 1990 when Indonesians decide to migrate (when Java attracted higher proportions of migrants rather than the island of origin). Turning to recent migrants, they constitute over 10 percent of the population only in Riau Islands (14.3\%) followed by West Papua $(8.2 \%)$. These provinces, and some others including East and Central Kalimantan, are attractive due to the economic opportunities they present. The creation of new provinces seem to have also led to an influx of migrants, such as in Bangka-Belitung, most likely due to the opening up of employment and economic opportunities. Yogyakarta attracts a sizable proportion of migrants $(7.4 \%)$ as a centre of education, who leave when they finish. The age profile of recent migrants is young, peaking in the 10-24 year old age group (see figure 5). The highest proportion of migrants comes from the provinces in Java. This is complicated by urbanisation and the megacity of Jabodetabek (Jakarta's metropolitan region that includes Jakarta, Bogor, Depok, Tangerang, South Tangerang, Bekasi). 

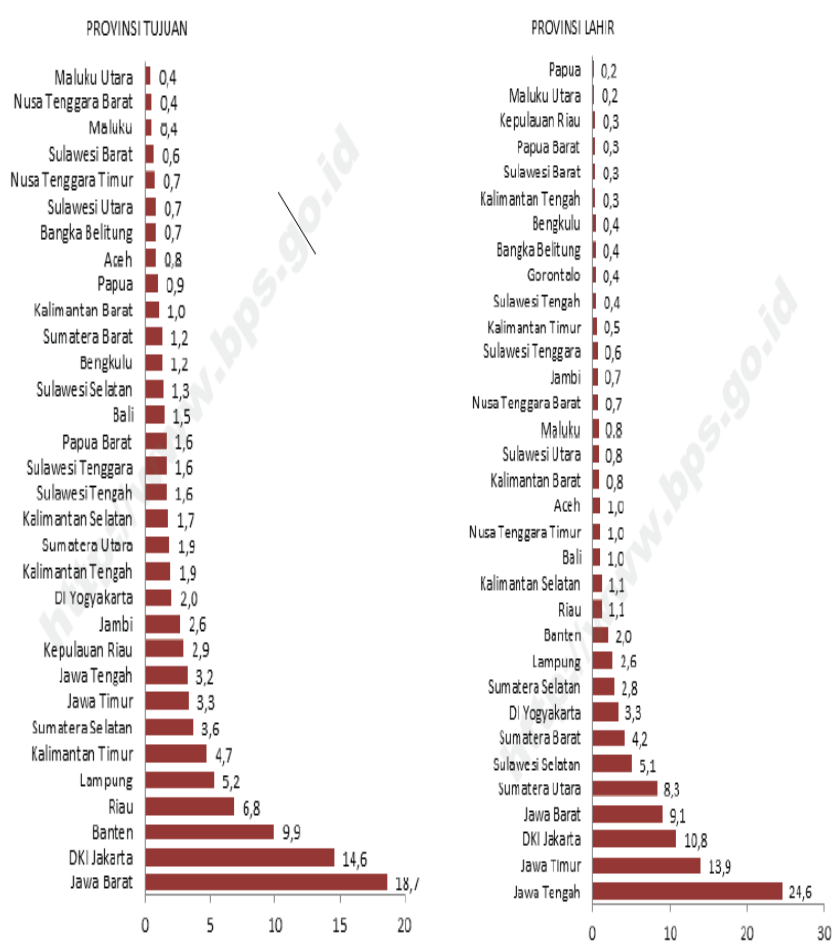

Fig 2: Lifetime migration by province of residenc eand province of birth (percentage) [15]

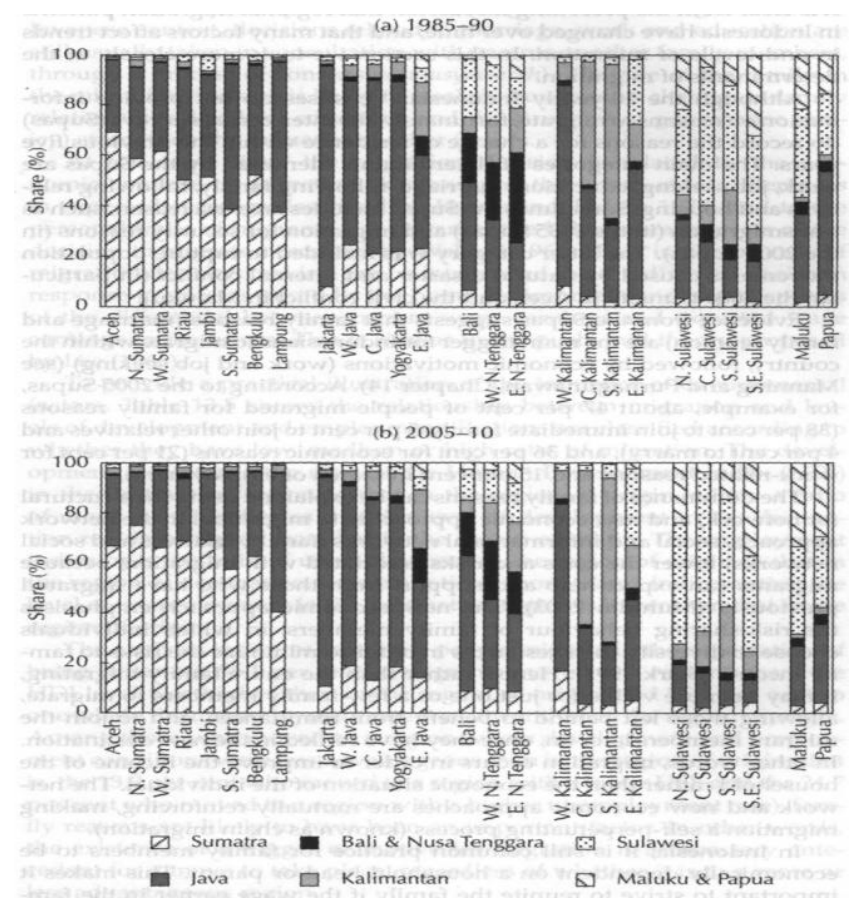

Fig 3: Distribution of new migrants by province of origin and island of destination, 1985-1990 and 2005-2010, [12]. Source: 1990 and 2010 popuation census (BPS).
TABle 3: Share And Net Share OF ReCEnt Migrants By Island AND PROVINCE (PERCENTAGE) [12]

\begin{tabular}{|c|c|c|c|c|c|c|c|c|}
\hline \multirow{2}{*}{$\begin{array}{l}\text { Region/ } \\
\text { province }\end{array}$} & \multicolumn{4}{|c|}{ Share in population $(\%)$} & \multicolumn{4}{|c|}{ Net share (\%) } \\
\hline & 1980 & 1990 & 2000 & 2010 & 1980 & 1990 & 2000 & 2010 \\
\hline $\begin{array}{l}\text { Indonesia } \\
\text { (million) }\end{array}$ & $\begin{array}{c}2.8 \\
(3.6)\end{array}$ & $\begin{array}{l}3.3 \\
(5.1)\end{array}$ & $\begin{array}{l}3.0 \\
(5.3)\end{array}$ & $\begin{array}{r}2.5 \\
(5.4)\end{array}$ & & & & \\
\hline $\begin{array}{l}\text { Sumatra } \\
\text { Aceh }\end{array}$ & $\begin{array}{l}5.1 \\
2.3\end{array}$ & 3.7 & 3.7 & $\begin{array}{l}2.8 \\
1.6\end{array}$ & & & & \\
\hline North Sumatra & 1.2 & 1.2 & 1.4 & 1.1 & -1.2 & $\begin{array}{r}0.2 \\
-1.9\end{array}$ & $\begin{array}{l}-9.3 \\
-2.2\end{array}$ & $\begin{array}{r}0.6 \\
-2.2\end{array}$ \\
\hline West Sumatra & 3.1 & 3.6 & 2.8 & 3.0 & -2.1 & -1.3 & -3.3 & -0.5 \\
\hline Riau & 5.2 & 8.6 . & 12.5 & 6.1. & 2.5 & 5.4 & 6.4 & 3.5 \\
\hline Riau Islands & & & & 14.3 & & & & 10.7 \\
\hline Jambi & 8.8 & 7.7 & 5.1 & 4.0 & 5.9. & 4.1 & 1.2 & -0.7 \\
\hline South Sumatra & 5.6 & 3.9 & 2.5 & 1.8 & 2.3 & 0.3 & 0.5 & 1.4 \\
\hline Bangka Belitung & & & 4.5 & 5.6 & & & 0.3 & -8.6 \\
\hline Bengkulu & 10.2 & 8.1 & 5.0 & 3.1 & 8.1 & 5.3 & 2.4 & 2.0 \\
\hline Lampung & 13.0 & 4.0 & 2.5 & 1.4 & 12.1 & 1.5 & 0.0 & 0.6 \\
\hline lava & 2.2 & 3.1 & 2.8 & 2.4 & & & & \\
\hline Jakarta & 13.6 & 11.1 & 9.1 & 7.4 & 7.0 & -2.2 & -1.9 & -2.8 \\
\hline $\begin{array}{l}\text { West Java } \\
\text { Banten }\end{array}$ & 2.2 & 4.3 & $\begin{array}{l}3.4 \\
8.6\end{array}$ & $\begin{array}{l}2.7 \\
4.9\end{array}$ & 0.4 & 2.8 & $\begin{array}{l}1.5 \\
5.7\end{array}$ & $\begin{array}{r}1.2 \\
-5.4\end{array}$ \\
\hline Central java & 0.8 & 1.5 & $\begin{array}{l}1.0 \\
1.2\end{array}$ & 1.0 & -3.3 & -3.1 & -2.4 & $\begin{array}{r}-5.4 \\
0.7\end{array}$ \\
\hline Yogyakarta & 3.8 & 6.0 & 6.7 & 7.1 & 1.1 & 1.5 & 2.3 & -9.4 \\
\hline East lava & 0.8 & 1.1 & 0.5 & 0.7 & -1.4 & -1.1 & -1.1 & 0.2 \\
\hline Bali \& Nusa Tenggara & 1.2 & 1.5 & 1.3 & 1.7 & & & & \\
\hline $\begin{array}{l}\text { Bali } \\
\text { W. Nusa Tenggara }\end{array}$ & 1.0 & $\begin{array}{l}2.6 \\
1.2\end{array}$ & $\begin{array}{l}1.5 \\
1.7\end{array}$ & $\begin{array}{l}2.9 \\
1.2\end{array}$ & $\begin{array}{l}-0.7 \\
-0.6\end{array}$ & $\begin{array}{l}0.4 \\
0.0\end{array}$ & $\begin{array}{l}1.9 \\
0.3\end{array}$ & 0.2 \\
\hline E. Nusa Tenggara & 1.0 & 0.9 & 0.8 & 1.2 & -0.4 & -0.7 & 0.5 & -0.4 \\
\hline Kalimantan & 4.5 & 5.1 & 4.3 & 3.9 & & & & \\
\hline West Kalimantan & 1.8 & 1.6 & 1.5 & 1.1 & 0.5 & 0.0 & 0.1 & 0.0 \\
\hline Central Kalimantan & 6.1 & 6.5 & 7.8 & 6.2 & 4.3 & 3.5 & 6.2 & 4.5 \\
\hline South Kalimantan & 3.4 & 4.2 & 3.3 & 3.2 & 0.9 & 1.0 & 1.0 & 1.5 \\
\hline East Kalimantan & 10.7 & 11.6 & 7.1 & 6.8 & 9.1 & 7.7 & 5.2 & 4.5 \\
\hline Sulawesi & 2.6 & 2.6 & 2.5 & 2.3 & & & & \\
\hline $\begin{array}{l}\text { North Sulawesi } \\
\text { Gorontalo }\end{array}$ & 2.4 & 1.5 & $\begin{array}{l}3.0 \\
1.3\end{array}$ & $\begin{array}{l}2.3 \\
2.9\end{array}$ & 0.4 & -0.7 & $\begin{array}{r}0.9 \\
-3.3\end{array}$ & $\begin{array}{r}0.1 \\
-1.3\end{array}$ \\
\hline Central Sulawesi & 7.6 & 4.6 & 4.2 & 2.7 & 6.2 & 2.8 & 2.5 & -6.3 \\
\hline South Sulawesi & 1.1 & 1.8 & 1.1 & 1.7 & -1.6 & -0.7 & -1.5 & 1.1 \\
\hline West Sulawesi & & & & 3.7 & & & & 2.0 \\
\hline Southeast Sulawesi & 6.4 & 6.2 & 7.0 & 3.3 & 2.8 & 3.0 & 5.7 & 2.3 \\
\hline Maluku \& Papua & 3.8 & 4.8 & 3.6 & 3.2 & 7 & 19 & & \\
\hline $\begin{array}{l}\text { Maluku } \\
\text { North Maluku }\end{array}$ & 3.8 & 4.3 & $\begin{array}{l}1.8 \\
2.5\end{array}$ & $\begin{array}{l}2.2 \\
2.7\end{array}$ & 1.7 & & $\begin{array}{l}-7.4 \\
-2,4\end{array}$ & $\begin{array}{r}-0.1 \\
1.1\end{array}$ \\
\hline Papua & 3.4 & 5.1 & 4.3 & 2.7 & 1.9 & 3.1 & 1.7 & $\begin{array}{l}1.1 \\
5.6\end{array}$ \\
\hline
\end{tabular}

Gambar 9

Distribusi Umur Migran Risen, 2010

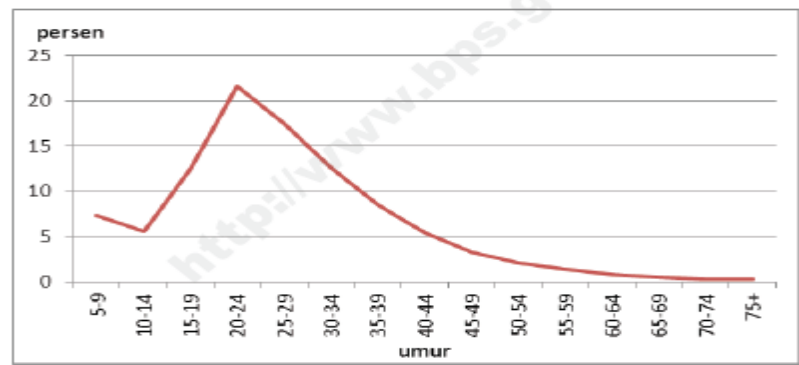

Fig 4: Age profile of recent [15]

Migrants seek opportunities, and those opportunities are increasingly in cities. Migrants move to cities at a ratio of $3: 1$ (20.4 million compared to 7.6 million) [15], and 72.7 percent of lifetime migrants live in cities (see figure 6). Indonesia had an urbanisation rate of $4.5 \%$ per annum since 1960 , which is very high [16]. It has slowed in the last decade (see table 3). Nonetheless, Indonesia has gone from a predominantly rural to having an urban population over 50 percent in two generations (49.7\% in 2010 census, which now would be over $50 \%$ ). Urban areas increased (through migration and reclassification of rural areas to urban) by 39 percent between 2000 and 2010 . Urban growth was higher on the islands outside Java $(3.8 \%)$ than Java (3.1\%) [10]. Cultural diversity will increasingly be located in Indonesia's cities. However, these cities are not without problems. Jabodetabek constitutes five of Indonesia's 11 cities with over a population of one million. The movements between Jakarta, West Java and Banten are generally between these cities, with Jakarta losing population to West Java and Banten as people move out from the urban core to the satellite cities. There are issues with water, 
flooding, transporation, enforcing spatial plans and coordination [17]. Cities, with all of their opportunities and problems, are the drivers and places of cultural diversity in Indonesia. ${ }^{4}$ This is demonstrated in Table 2, where the average percentage of the largest ethnic group in cities $(62.50 \%)$ was almost ten percent below the same figure for regencies $(71.90 \%)$. Cities should be the focus of multiculturalism.

TABLE 4: Total AND URBAN POPULATION In INDONESIA, 2000-2010 [12]

\begin{tabular}{|c|c|c|c|}
\hline & Java & $\begin{array}{l}\text { Outer } \\
\text { islands }\end{array}$ & Indonesia \\
\hline \multicolumn{4}{|l|}{2000} \\
\hline Total population $(000)$ & 120,429 & 83,027 & 203,456 \\
\hline Annual rate of population growth, $1990-2000(\%)$ & 1.11 & 1.56 & 1.35 \\
\hline Urban population (000) & 58,874 & 26,370 & 85,244 \\
\hline Proportion of population living in urban areas & 0.487 & 0.328 & 0.419 \\
\hline Share of urban population (\%) & 69.1 & 30.9 & 100.0 \\
\hline Annual rate of urban population growth (\%) & 4.38 & 4.43 & 4.40 \\
\hline \multicolumn{4}{|l|}{2010} \\
\hline Total population $(000)$ & 136,611 & 101,031 & 237,641 \\
\hline Annual rate of population growth, $2000-2010(\%)$ & 1.25 & 1.98 & 1.49 \\
\hline Urban population $(000)$ & 79,949 & 38,373 & 118,322 \\
\hline Proportion of population living in urban areas & 0.608 & 0.379 & 0.498 \\
\hline Share of urban population (\%) & 67.6 & 32.4 & 100.0 \\
\hline Annual rate of urban population growth (\%) & 3.10 & 3.79 & 3.33 \\
\hline
\end{tabular}
Source: Central Board of Statistics (2011) (http://www.bps.go.id) and Firman (2004)

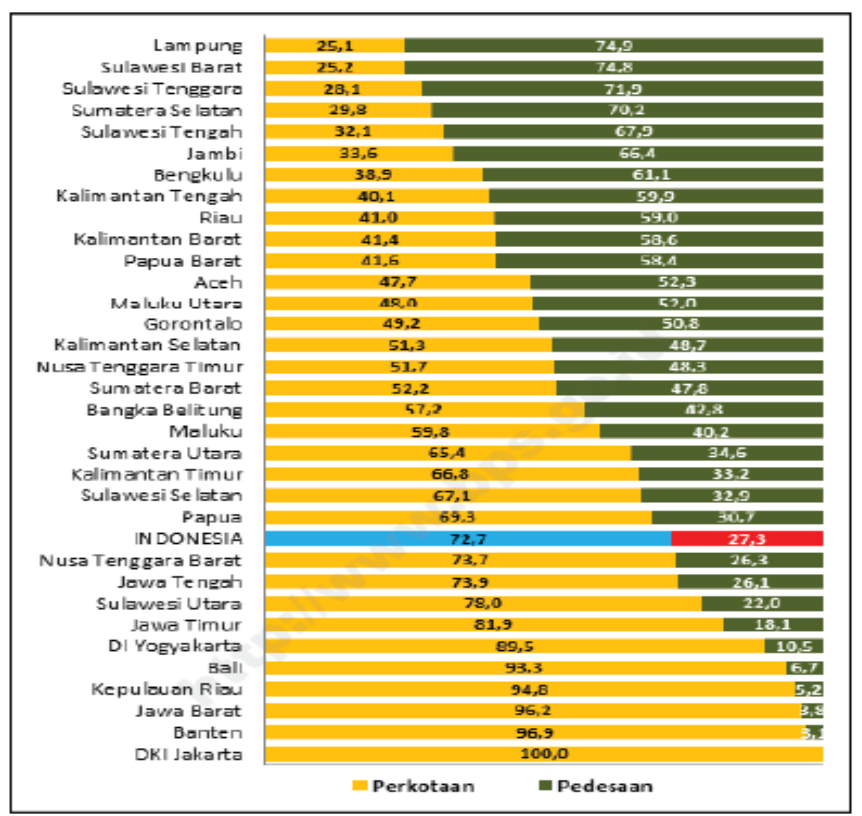

Fig 5: Lifetime migration by province and city/rural residence (percentage) [15]

\footnotetext{
${ }^{4}$ The trend of migrants moving to cities is not uniformly the case. In some districts in new provinces, such as North Mamuju in West Sulawesi and four districts in Papua, there was high migration to rural districts, which drives cultural diversity in rural districts. Ref [12] posits this migration is likely to be due to the opportunities that new provinces are thought to generate for migrants.
}

\section{CUlturAl POLICY AS MULTICULTURALISM: A HISTORICAL PERSPECTIVE ${ }^{5}$}

Cultural policy in Indonesia began during colonialism. The study of Indigenous ethnic traditions (adat) began with the amateur endeavours of colonial administrators but by the twentieth century was a state-sponsored undertaking that sought to divide Indonesia into understandable and governable regions for Dutch administrators [18]. The colonial state then used ethnic divisions as a way of dividing both the population and the geographical expanse of Indonesia. Unlike today, Europeans ranked cultures hierarchically with European cultures at the apex, and other cultures considered on a developmental path to the same destination. According to Governor-General De Jong in 1936, Indonesians needed another 300 years before they were sufficiently developed to have full autonomy from the Netherlands. The colonial cultural institutions for Indonesians, like Balai Poestaka, produced different language publications for the large ethnic groups in order to try to 'educate' them, including combating popular (and often nationalist) publications that were considered unethical or inferior in quality. Colonial era multiculturalism divided the Indonesian population into ethnic groups with different languages, customs and regions, but broadly similar developmental paths. This suited the Dutch understanding of their role as coordinating a set of smaller populations, and had its strongest expression in the negotiated plan for short-lived Federal Indonesian Republic (Republik Indonesia Serikat) in 1949; a set of ethnically divided provinces that sat within an Indonesian federation.

Indonesian nationalists strongly opposed the colonial model of Indonesian multiculturalism, and indeed to some degree the concept of multiculturalism itself due to their emphasis on unification. In 1928, the Sumpah Pemuda called for 'one Fatherland, Indonesia; one nation, Indonesia; an one language, Bahasa Indonesia, the language of unity.' Similarly, both sides in the Polemik Kebudayaan in the mid-1930s assumed that a single national culture would emerge with the new nation. Indonesians rejected the 1949 federal model, and in 1950 a new constitution While the 1945 constitution gave the state the power to make cultural policy, it had little opportunity to do so until the end of the war of independence, at which time Indonesia's new leaders formed a new constitution. The 1950 Constitution ${ }^{6}$ sought to guarantee cultural freedoms in clause 50:

The government will protect the freedom
to partake in culture, the arts and
science. Respecting this principle, the
government will, to the greatest extent
possible, promote the development of

5 This information, with the exception of my analysis of the 2017 cultural policy legislation, is taken from [19].

${ }^{6}$ While the 1945 constitution gave the state the power to make cultural policy, it had little opportunity to do so until it was returned in 1957. Hence I leave my discussion of the 1945 constitution until after the 1950 constitution. 
nationalism in culture, the arts and science.

The emphasis of cultural policy at this time was on the creation of a new national culture with an emphasis on synthesis, not just on indigenous ethnic cultures, but also elements of 'western' culture. Political leaders were also very critical of some elements of what they labelled western culture (such as long hair on boys and the jitterbug). A state initiative at this time that demonstrates their commitment to a new national culture was the promotion of Serambling Duabelas, invented in 1954 by a cultural bureaucrat in Medan and promoted throughout Indonesia as an appropriate dance for nationalist youth.

By the mid-1950s, political and economic problems (in particular the divisions between Java and the other islands) led to shifts in both political leadership and how Indonesian culture was conceived. From 1956 regional cultures became more essential to the articulation of cultural policy as synthesis was replaced by recognition of indigenous cultures. This was reinforced by the Sukarno-led return to the 1945 Constitution. The 1945 constitution included state direction of culture in clause 32:

\section{The government shall advance Indonesian Culture.}

This clause was accompanied by a now-familiar clarification that gave definition to 'Culture':

The culture of the nation is culture that
arises as the product of the character of
the entire people of Indonesia. Old and
authentic culture is found in high
cultural achievements [Lit. peaks of
culture] in regions throughout Indonesia
[and is] considered the culture of the
nation. Cultural effort must be directed
to the advancement of civilization,
culture and unification, and should not
reject new materials from foreign culture
that can develop and enrich the culture
of the nation and raise the level of
humanity of the Indonesian nation.

This model of Indonesian multiculturalism is still important today.

The application of this model of multiculturalism in cultural policy was very different in 1960-65 than after 1965 . Due to Sukarno's emphasis on mobilisation and revolution, party-affiliated cultural groups (such as LEKRA, LESBUMI, etc.) took the lead in interpreting Sukarno's directives, leading to strongly political art within ethnic artistic traditions. The events of 1965 stopped political mobilisation in cultural policy. In the contemporary national arts, artistic groups and individuals who argued that art should not be political were allowed to create new national arts institutions like Taman Ismail Marzuki. In the regional arts, many arts stopped entirely due to their previous political affiliations and returned under the patronage of political leaders and military figures affiliated with the New Order regime. The economic growth of Indonesia under the New Order, first through international aid and then through oil revenues, allowed the state to hugely expand its cultural policy initiatives. By 1998, the cultural bureaucracy recorded that it employed 74,722 people throughout Indonesia, all reporting to Jakarta.

New Order multiculturalism tied ethnic groups to different state administrations within Indonesia. This could be at the provincial level, such as the Minangkabau in West Sumatra and the Balinese in Bali, or at the district level, such as occurs in Cirebon. Cultural policy was developmentalist in orientation, with its primary justification being to prepare Indonesians for development through the removal of cultural barriers and strengthening indigenous cultures to withstand threats from western popular culture. One way of demonstrating these alignments is through the cultural competitions (lomba) that were run in the Cultural Centres (Taman Budaya) throughout Indonesia during art week (pecan kesenian).

The preparations for Arts Week began months ahead with a request for each regency and city to choose a group of artists from an indigenous genre to represent it. Either a competition was held at the city or regency level or a group was chosen by a committee to perform at the Arts Week festival in the provincial capital city, and then a representative would win the opportunity to represent the province in a performance in Jakarta. The following list shows the criteria used to assess performances at the West Java level in Arts Week in 1983 [20]:

- Qualities of the genre of art that was considered to increase the prospect of positive interest from observers, the jury and spectators;

- The extent to which the art is authentically West Javanese when viewed from a national viewpoint;

- The extent to which the art still contains its ambience or the spirit of traditional community art after there is a process of 'training' from peers; and

- The extent to which the art, and its accompanying music, is established and has received 'training'.

Multiculturalism in this model changes ethnic culture to accord with state-defined ideas about development, and ties it to a specific region and administration. The 'peaks of culture' model therefore aligned administrative and a dominant ethnic culture together. This model creates problems when two or more ethnic cultural groups are of a similar size, and makes the representation of minority cultures in official programs symbolic at best. We can think of this has hierarchical multiculturalism.

The problem with hierarchical multiculturalism is that it struggles to cope with cultural diversity at the level of the city, and at times province. Indonesia's demographic transition in particular places pressure on hierarchical multiculturalism. As increasing numbers of younger Indonesians gain higher levels of education and migrate to seek new opportunities, their destinations become increasingly culturally diverse. These destinations are for the most part cities. While cities in Java, 
due most likely to higher levels of development, were favoured destinations in the 1980s and 1990s, the higher level of development in the islands outside Java has shifted migration patterns towards these locations, slowing interisland migration. However, the migration of the Javanese from Central and East Java in particular has continued for the last 30 years and shows little sign of slowing down. A major issue that stems back to the 1990s is the lack of investment in infrastructure in cities [16]. While Indonesia has invested in cities at a rate of 3-4 percent of GDP, this trails other countries with high levels of urbanisation like China and India. This has led to lower returns on urbanisation in Indonesia than is the case in other countries. In short, there are issues with migrants' prospects in their new locations.

An important outcome of hierarchical multiculturalism is the creation of new administrative units, or pemekaran, that followed decentralisation in 2002. The provinces that split tended to have two large ethnic populations. For instance, Banten separated from the Sudanese in West Java, Gorontalo from the Minahasa in North Sulawesi, and the Tobelo in North Maluku from the Butonese in Maluku [14]. There are also instances of indigenous ethnic groups splitting from regions that have large Javanese populations, such as Bangka-Belitung from South Sumatra, and North Kalimantan (Buginese) from East Kalimantan. One reversal of this was the separation of West Papua (Javanese) from Papua (Dani). This has also occurred at the district level, with an increase from 340 in 2000 to 514 in 2014 [14]. Hierarchical multiculturalism drives groups when they become large enough to establish an administrative unit that they can control. However, this could continue indefinitely (although at a slower rate) as migration will continue in Indonesia, driven by Indonesia's demographic transition.

These are not the only issues that confront Indonesia's hierarchical multiculturalism. First, the underinvestment in infrastructure in cities affects the living conditions of new, young migrants, and could exacerbate tensions between migrants and inhabitants. Political agitation and violence is most likely where livelihoods and living conditions are difficult. Second, hierarchical multiculturalism does not support the expression of cultural diversity within a city. Ref [21] has highlighted the trend amongst some hard-line Islamic groups to repress opinions and practices that they oppose through large and at times violent protests. He argues that these Islamic political operatives are changing public space in Indonesia in ways that has serious implications for multiculturalism. Similarly, after a campaign that indicated he would work to support human rights and freedom of expression, President Joko Widodo has moved away from protecting human rights, pursuing corruption and nepotism, and ensuring freedom of speech to narrower development goals [22]. This removes avenues for the expression of cultural diversity within increasingly diverse cities.

\section{CONCLUSION}

The hierarchical multiculturalism of contemporary Indonesia, which was shaped during the New Order period, is in tension with powerful demographic forces that will continue to shape Indonesia for the foreseeable future. The creation of new districts in the Reform era is one way that these tensions are being managed, although this has also undermined the efficiencies and better governance that decentralisation has brought elsewhere [8][22]. Ref [8] has argued that this constitutes a success for decentralisation. While this maybe the case in the short term, and setting aside the failures of decentralisation, hierarchical multiculturalism does not address these underlying processes of cultural diversification.

However, through education there is an opportunity to explore and advocate for a more appropriate form of Indonesian multiculturalism. This multiculturalism should be based on place rather than ethnic group, and seek to emphasise contemporary experiences, practices and issues. It should embrace all of the ethnic practices present in the place, whatever their origin, and also include contemporary cultural and artistic expression. This multiculturalism is already present in many locations in Indonesia due to residents' responses to the forces I have been discussing, but it struggles to penetrate into government policy. This place-based multiculturalism should be the focus of research and educational efforts, with an emphasis on how different groups work to claim local rights (what [23] calls urban citizenship). Empowering local government to dialogue with these groups in tandem with existing residents and their organisations is how Indonesian cities will realise the full benefits of urbanisation. The new cultural policy legislation (UU 52017 Pemajuan Kebudayaan) holds within it the seeds of this approach as it empowers local groups to articulate their ideas and concerns to local government, which then shapes cultural policy. These types of activities can help to offset tensions between hierarchical multiculturalism and demographic change, but they are most effective within a place-based multiculturalism that encourages the expression of cultural diversity and reduces barriers to Indonesians seeking opportunities, wherever they may be.

\section{ACKNOWLEDGMENT}

I would like to acknowledge the role of Obor, in particular Andreas Haryono, in facilitating my travel to Indonesia and leading me to write this paper. The content, and any shortcomings, are entirely my own. This paper was prepared for the International Conference on Social Sciences. I would like to thank the organizing committee for the opportunity to prepare and present this paper.

\section{REFERENCES}

[1] C. Geertz, The religion of Java, Glencoe, Ill: Free Press, 1960

[2] H. Crouch, "Patrimonialism and military rule in Indonesia", World Politics, 31(4), 1979, pp 571-587.

[3] R. Robison, \& D. S. G. Goodman, (Eds.), The New Rich in Asia: Mobile Phones, McDonalds and Middle-Class Revolution, London: Routledge, 1996

[4] G. Forrester \& R. J. May, (Eds.), The Fall of Soeharto, Bathurst: Crawford House, 1998

[5] H. Schulte Nordholt, \& G. Van Klinken, (Eds.), Renegotiating boundaries: local politics in post-Suharto Indonesia, Leiden: KITLV, 2007

[6] G. Van Klinken, \& W. Berenschot, (Eds), In search of Middle Indonesia: middle classes in provincial towns, Leiden \& Boston: Brill, 2014 
[7] G. Van Klinken, "The Maluku Wars: Bringing Society Back In", Indonesia, 71(71), doi:10.2307/3351455, 2001, pp 1-26

[8] M. Mietzner, "Indonesia's decentralization: the rise of local identities and the survival of the nation-state, In H. Hill (Ed.), Regional dynamics in a decentralized Indonesia", Singapore Institute of Southeast Asian Studies, 2014, pp. 45-67

[9] N. Glazer, "Is assimilation dead?", Annals of the American Academy of Political and Social Science, 530, 1993, pp 122-136

[10] T. Firman, "Demographic Patterns of Indonesia's Urbanization, 20002010", Continuity and Change at the Macro Level,Vol. 5, 2016

[11] P. McDonald, "The demography of Indonesia in comparative perspective, Bulletin of Indonesian Economic Studies", 50(1), doi:10.1080/00074918.2014.896236, 2014, pp 29-52

[12] S. Muhidin, Migration patterns: people on the move, In H. Hill (Ed.), "Regional dynamics in a decentralized Indonesia", Singapore Institute of Southeast Asian Studies, 2014, pp. 317-341

[13] A. Ananta, E. N. Arifin, M. S. Hasbullah, N. B.Handayani, \& A. Pramono, Demography of indonesia's ethnicity, Singapore: Institute of Southeast Asian Studies, 2015

[14] E. N. Arifin, A. Ananta, D. Utami, N. B. Handayani, \& A. Pramono, "Quantifying Indonesia's ethnic diversity: statistics at national, provincial, and district levels", Asian Population Studies, 11(3), doi:10.1080/17441730.2015.1090692, 2015, pp 233-256.

[15] D. Handiyatmo, Migrasi Internal Penduduk Indonesia: Hasil Sensus Penduduk 2010 [Internal migration of the Indonesian population: Results of the 2010 Population Census], 2011
[16] B. D. Lewis, Urbanization and Economic Growth in Indonesia: Good News, Bad News and (Possible) Local Government Mitigation, Regional Studies, 48(1), doi:10.1080/00343404.2012.748980, 2014, pp 192-207.

[17] T. Firman, The urbanisation of Java, 2000-2010: towards 'the island of mega-urban regions', Asian Population Studies, 13(1), doi:10.1080/17441730.2016.1247587, 2017, pp 50-66

[18] F. Gouda, Dutch culture overseas: colonial practice in the Netherland Indies, 1900-1942, Amsterdam: Amsterdam University Press, 1995

[19] T. Jones, Kebudayaan dan kekuasaan di Indonesia: kebijakan budaya selama abad ke 20 hingga era reformasi (E. R. Terre, Trans.), Jakarta: Obor, 2015

[20] W. Wibisana, Pekan seni musik dan tari rakyat tradisional tingkat Jawa Barat 1983, Kawit: Majalah Kebudayaan Jawa Barat, 37(8), 1983, pp 12,21 .

[21] M. C. Ricklefs, Islamisation and Its Opponents in Java, A Political, Social, Cultural and Religious History, c, 1930 to Present, Honolulu: University of Hawai'i Press, 2012

[22] E. Warburton, "Jokowi and the New Developmentalism", Bulletin of Indonesian Economic Studies, doi:10.1080/00074918.2016.1249262, 2016, pp 297-320.

[23] O. Yiftachel, "Epilogue - from 'Gray Space' to Equal 'Metrozenship'? Reflections On Urban Citizenship", International Journal of Urban and Regional Research, 39(4), 726-737, doi:10.1111/1468-2427.12263, 2015 